\title{
Profesyonel Turist Rehberlerinin Kişisel Gelişimi ve Mesleki Donanımı Üzerine Bir Araştırma*
}

\section{A Study on Personal Development and Professional Competence of the Professional Tourist Guides}

\author{
Öğr. Gör. Hediye GÜRSOY \\ Nişantaş1 Üniversitesi, Uygulamalı Bilimler Yüksekokulu, Türkiye \\ Nişantaşı University, School of Applied Science, Turkey \\ E-Mail: memberhediye@ hotmail.com \\ Doç. Dr. Sabahattin KARAMAN \\ Balıkesir Üniversitesi, Sosyal Bilimler Enstitüsü, Türkiye \\ Balıesir University, Institute of Social Science, Turkey \\ E-Mail: skaraman@balikesir.edu.tr
}

\section{$\ddot{O} z$}

Amaç ve Önem: Bu çalışmada, turist rehberlerinin kişisel ve mesleki yetkinliklerine ait görüşlerinin, kişisel gelişim çabalarının ve performans yeterliliklerine verdikleri önemin belirlenmesi amaçlanmaktadır. Turistleri gittikleri ülke veya bölgede genellikle ilk karşılayan ve onlara tatilleri boyunca eşlik eden, yol gösteren, yardımcı olan, bilgi veren kısacası tatili daha değerli hale getiren turist rehberlerinin performansları, turizm sektörünün başarısına etki eden önemli faktörlerden biridir. Hizmet verdiği turistler, birlikte iş yaptığı işletmeler ve temsilcisi ve tanıtıcısı olduğu ülkesi açısından mesleğin taşıdığı önem dikkate alındığında, bu mesleği icra eden bireylerin birtakım kişisel ve mesleki özelliklere sahip olmaları ve bunları sürekli geliştirmeleri gerekmektedir.

Yöntem: Verilerin elde edilmesinde nitel araştırma yöntemlerinden biri olan görüşme tekniği kullanılmıştır. Görüşmeler sonucunda toplanan bilgiler betimsel ve içerik analiziyle değerlendirilmiştir.

Bulgular: Verilerin analizi sonucunda dört ana tema oluşturulmuştur. Bu temalar sırasıyla; turist rehberliği mesleğine ilişkin görüşler, turist rehberinin kişisel ve mesleki özellikleri, turist rehberinin kişisel ve mesleki gelişim çabası ve turist rehberinin mesleki sorunlarla mücadelesidir. Oluşturulan temalar ve temalara ait kodlar listesi tablolar halinde ayrıntılı olarak incelenmiştir. Çalışma sonucunda turist rehberlerinin kişisel ve mesleki özelliklerini geliştiren, kişisel ve mesleki gelişimi için çaba gösteren ve yetkinlik düzeyleri yüksek bireyler oldukları belirlenmiş̧ir.

Özgünlük/Bilimsel Katkı: Çalışma turist rehberlerinin kişisel ve mesleki gelişim süreçlerine verdikleri önemin genel bir profilini çizmektedir. Daha önce yapılmış olan çalışmalar incelendiğinde turist rehberlerinin kişisel gelişimiyle ilgili yapılan çalışmaların kısıtlı olduğu ve bu nedenle ilgili alanyazına katkı sağlayacağı düşünülmektedir. Ayrıca lider pozisyonda çalışan farklı meslek mensuplarına yapılabilecek araştırmalar için örnek teşkil edeceği düşünülmektedir.

Anahtar Kelimeler: Kişisel gelişim, donanım, mesleki gelişim, turist rehberi, performans.

Makale Türü: Araştırma makalesi

Atıf için (for cited); Gürsoy, H. ve Karaman, S. (2019). Profesyonel Turist Rehberlerinin Kişisel Gelişimi ve Mesleki Donanımı Üzerine Bir Araştırma, Turist Rehberliği Dergisi, 2(2), 88-103.

* Bu makale, Hediye Gürsoy tarafindan hazırlanan "Profesyonel Turist Rehberlerinin Kişisel Gelişimi ve Mesleki Donanımı Üzerine Bir Araştırma'” başlıklı yüksek lisans tezinden üretilmiştir. 
Turist Rehberliği Dergisi (TURED) \& Yı1. 2019, Cilt. 2, Sayı. 2

Journal of Tour Guiding (JOTOG) \& Year. 2019, Volume. 2, Issue. 2

\begin{abstract}
Purpose and Importance: In this study, it is aimed to determine the opinions of tourist guides about their personal and professional competencies, their personal development efforts and the importance they attach to performance competencies. The performances of the tourist guides, who usually meet the tourists first in the country or region they visit and accompany them during their holidays, are one of the important factors affecting the success of the tourism sector. Considering the importance of the profession of guidance, individuals performing this profession should have some personal and professional characteristics and should develop them continuously.
\end{abstract}

Methodology: Interview technique, which is one of the qualitative research methods, was used to obtain the data. The information collected at the end of the interviews was evaluated with descriptive and content analysis.

Findings: As a result of the data analysis, four main themes were created. These themes are; opinions about the profession of tourist guidance, personal and professional characteristics of tourist guide, personal and professional development effort of tourist guide and struggle of tourist guide with professional problems. The themes created and the list of codes related to the themes were examined in detail in tables. As a result of the study, it has been determined that tourist guides are individuals who develop personal and professional characteristics, struggle for personal and professional development and have high level of competence.

Originality/Value: The study provides a general profile of the personal and professional development processes of tourist guides. Especially, it is thought that the studies on the personal development of tourist guides are limited and therefore will contribute to the profession. In addition, it is thought that it will serve as an example profess researches that can be carried out for different professionals working in the leading personnel position.

Keywords: Personal development, equipment, professional development, tourist guide, performance.

Paper Type: Research article

\title{
Giriş
}

Turizm, basit bir olgudan küresel bir sanayiye doğru en hızlı büyüyen sektörlerden biridir. Son yüzyılda turizm sektöründe özellikle kitle turizminde yaşanan düşüş, özel ilgi alanlarına sahip küçük grupları ve daha sık kısa süreli konaklamaları arttırmıştır. Bu gelişmeler sektördeki rekabetin artmasına, ülke veya bölgenin turizm potansiyelinin vurgulanması için mücadele edilmesine neden olmuştur. Bu noktada sektörde eğitimli ve nitelikli çalışan talebi oluşmaktadır. Turistik seyahat ve konaklamaya katma değerin dâhil edilmesinin ilgili çalışana bağlı olabildiği bilinerek, turizm sektöründe çalışanların, özellikle sektörde önemli bir yere sahip turist rehberlerinin eğitimi ve niteliğinin kaliteli olması gerekmektedir. Dolayısıyla turist rehberlerinin eğitim ile belirli bir bilgi, beceri ve yeterlilik seviyesine ulaşmaları, turistlerin gereksinim ve ihtiyaçlarını göz önünde tutarak kişisel ve davranışsal becerilerini geliştirmeleri gerekmektedir (Lovrentjev, 2015: 556; Kassawnh, et all., 2019: 1). Bu kapsamda bu çalışmada, turist rehberlerinin kişisel ve mesleki yetkinliklerine ait görüşlerinin, kişisel gelişim çabalarının ve performans yeterliliklerine verdikleri önemin belirlenmesi amaçlanmaktadır. Bu doğrultuda çalışmada ilk olarak kişisel gelişim ve mesleki donanım kavramları ve bu kavramların turist rehberliği mesleği açısından değerlendirilmesi yapılmıştır. Çalışma amacına uygun verilerin elde edilmesinde turist rehberleriyle birebir görüşmeler gerçekleştirilmiş ve alınan görüşlerin değerlendirilmesi yapılmıştır. Çalışmada son olarak, konuyla ilgili yapılan değerlendirmeler özet bir bakışla sunulmuş, sonuçları tartışılmış ve araştırmacılara, ilgili taraflara önerilerde bulunulmuştur. 


\section{Kişisel Gelişim ve Turist Rehberliği}

Kişisel gelişim; yönetim, motivasyon, iletişim, düşünce, zeka, öğrenme gibi çok farklı ve çeşitli konuların alanına giren geniş bir kavramdır. Birçok tanımı bulunmakla birlikte temel olarak kişinin bireysel hedeflerine ulaşma gayretidir (Ekşi, 2011: 3-11). Kişisel gelişim, bireyin yeterli olmadığını düşündüğü bir durumdan yeterli olabilmek adına gösterdiği gelişimdir. $\mathrm{Bu}$ süreçte birey çevresindeki her şeyin bir değişim halinde olduğunu görür ve bu değişime uyum sağlaması ve kendisini her yönden geliştirmesi gerektiğinin bilincindedir. Kişisel gelişim yaşam boyu sürdürülen bir gelişimdir (Balaban ve Çakmak, 2016: 3). Bu gelişimin ilk adımı ise bireyin kendisini tanımasıyla başlar. Çünkü kendi kişilik özelliklerini bilmeyen bireyler kişisel gelişimleri için doğru adımlar atamamaktadır. Her birey farklı kişilik özelliklerine sahiptir. Dolayısıyla her bireyin gereksinim duyduğu gelişim alanı da farklılık göstermektedir. $\mathrm{Bu}$ nedenle birey gelişim göstermek istediği alanı tespit edip o yönde hareket etmelidir. Bunu başarabilmesi bireyin kendisini iyi tanımasıyla mümkündür (Limoncu, 2015: 10).

Kişisel gelişim, bireylerin performans ve verimliliğini arttırıcı faaliyetleri içeren bir uyum sürecidir. Kişinin hedeflerine daha kolay ulaşmasına, başkalarıyla sağlıklı ilişkiler kurabilmesine, olaylara farklı veya gerçekçi bakış açılarıyla bakabilmesine yardımcı olur. Motivasyonu arttırarak bir işin başarılmasına etki eder. Kişisel gelişimi ilerledikçe birey, duygu ve düşüncelerini kontrol altına alabilen, daha sosyal ve enerjik bir kimlik kazanır. Bireylerin yaşam kalitesini arttırıcı değişim ve gelişmeleri beraberinde getirecek bu beceriler ile bireyler, odaklanılan hedefe planlı bir şekilde ulaşacaktır (Pekkan vd., 2018: 772; Genç ve Fidan, 2019: 152).

Kişisel hayatta başarılı olmayı sağlayan kişisel gelişim özellikle iş hayatında da bireylerin daha iyi fırsatlar elde etmelerine yardımcı olmaktadır. Çünkü sürekli öğrenme hevesi duyan, kendini geliştiren ve sorumluluklarını yerine getiren çalışanlar her zaman işverenler tarafından daha değerlidir (Tat, 2007: 141). Özellikle turist rehberliği gibi farklı sektörlerle bir arada çalışmayı ve farklı insanlarla bir arada olmayı gerektiren bir meslekte turist profilinde ve sektörlerde yaşanan gelişmelere paralel olarak rehberlerin kişisel gelişimlerine ve kişisel gelişimin bir parçası olarak mesleki gelişimlerine önem vermeleri gerekmektedir.

Pek çok farklı insanla farklı destinasyonlarda vakit geçiren ve hizmet sunan turist rehberleri ülkesini ve kültürünü en iyi bilen ve en doğru şekilde aktaran bireylerdir. Dolayısıyla rehberlerin sürekli kendini yenileyen, insanlarla rahat iletişim kurabilen, bilgisini etkili aktarabilen, güler yüzlü ve aktif kişiler olmaları gerekmektedir. Eşlik ettiği turist grubuna liderlik edebilmeli, grup üyelerinin motivasyonunu arttırabilmeli, yardımsever, nazik bir tutum sergilemeli, dış görünümüne özen göstermeli ve meslek etiğine uygun davranışlar sergilemelidirler. Turist rehberleri görevlerini yerine getirirken ülkesini en iyi şekilde tanıtma ve birlikte çalıştığı acentanin iyi bir temsilcisi olmanın yanında tur raporlarının hazırlanması ve teslim edilmesi gibi örgütsel, kişisel bakımına özen gösterme ve iş ile özel hayatını ayırabilme gibi bireysel sorumlulukları da üstlenmektedirler. Bu noktada rehberler sorumluluk düzeyi yüksek ve öz denetimli bireyler olmaları gerekmektedir ( Saltık ve Dönmez, 2018: 89-91).

Yönettiği turlarda çok çeşitli sorunlarla karşı karşıya kalabilen rehberler en yetkili ve sorumlu kişiler olarak en doğru ve hızlı bir şekilde çözüm üretebilmelidirler. Belirli bir zaman dilimi içerisinde gerçekleşen turlarda rehberin zamanı etkili ve verimli kullanabilmesi gerekmektedir. Ayrıca mesleğini yerine getirirken turist grubu haricinde pek çok insanla da iletişim ve etkileşim halinde olan rehberler karşılıklı iyi ilişkiler kurmalı ve bunu dengede tutabilmelidirler. (Akköz, 2015; Doğan, 2018; Şahin ve Kızılırmak, 2018). Diğer bir yönden bakıldığında ise bu kadar rol ve sorumluluğu üstlenmesi beklenen turist rehberlerinin duygusal olarak bazı sorunlar yaşamaları da muhtemeldir (Kaya ve Özhan, 2012: 110). Fakat turist 
rehberliği mesleği yenilenmenin zorunlu olduğu dinamik bir meslektir. Bir rehber gündemi takip etmeli, sürekli okuyup araştırmalı ve bilgisini yenilemelidir. Dolayısıyla bu meslekte başarılı olmak ve bu başarının devamlılı̆̆ını sağlamak için rehberlerin kişisel yönde kendilerini sürekli geliştirmeleri gerekmektedir.

\section{Mesleki Donanım ve Turist Rehberliği}

Mesleki donanım, bireyin mesleğini yerine getirebilmesini sağlayan niteliklerdir. Mesleki donanım bireyin mesleğinde yetkin olması demektir. Mesleki performansın kazanılmasında ve geliştirilmesinde gerekli bilgi, beceri ve tutumlardan oluşur. Genel bir ifadeyle, bireyin işinde üstlendiği görev ve sorumluluklarını etkileyen, performansla ilişkili, eğitim ile geliştirilebilen, meslekte belirlenmiş standartlarla ölçülebilen bilgi, beceri, davranış, tutum ve kişisel özelliklerin tümüdür (Karahan ve Kav, 2018: 161). İşverenlerin çalışanlarından beklediği performansın belirlenmesini sağlayan araçlardır. Çalışanların hem kendileri hem de işletmeleri için belirlenen hedefleri en iyi şekilde gerçekleştirebilmelerini sağlayan bir rehberdir (Biçer ve Düztepe, 2003: 14). Mesleki olarak donanımlı bireyler, mesleki bilgisi olan ve bunu kendi yorumunu da katarak etkili bir şekilde aktarabilen, yenilikleri takip eden ve bu yeniliklere uyum sağlayabilen çalışanlardır (Karayağız, 2018: 50).

Mesleki donanım yapılan açıklamalardan da anlaşılabileceği üzere temel olarak üç bileşenden oluşmaktadır. Bunların ilki mesleki bilgidir. Her meslekte gerekli donanımın kazanılmasında birtakım kavramsal bilgiye ihtiyaç duyulmaktadır. Bireylerin donanım kazanmalarındaki ilk adımı gerekli mesleki bilgiye sahip olmaktır. Özellikle eğitim ile kazanılan bilgiyi çalışanların mesleki hayatları boyunca kullanması mümkün olmamaktadır. Dolayısıyla çalışanlar zamanla yeni bilgilere ihtiyaç duymaktadırlar. Bilginin sürekli yenilenmesi çalışanların da mesleki bilgilerini sürekli yenilemelerini zorunlu kılmıştır (İskender, 2011: 51; Ayra ve Kösterelioğlu, 2015: 18). Mesleki donanımın ikinci bileşeni mesleki becerilerdir. Beceri, bilgiye sahip olan bireyin bu bilgiyi uygulamaya geçirmesidir. Bir işi yapabilme gücü, görevini yerine getirebilme kabiliyetidir. Beceri sadece bilmek ve bilineni uygulamakla sinırlı değildir. Karşılaşılan bazı karmaşık durumların ya da sorunların üstesinden gelmek de beceri gerektirmektedir. Beceri, teorik bilgilerle ya da eğitim ile geliştirilmez. Çalışanların gösterecekleri gayretlerle ve gerçek uygulamalarla geliştirilir. Ayrıca becerinin düzeyi gelişen bilgi ve değişen koşullara göre geliştirilmelidir (Güneş, 2012: 3). Mesleki donanımın üçüncü bileşeni ise mesleki değerler, etik ilkeler ve tutumlardır. Her meslekte çalışanların o mesleğe özgü ya da evrensel bazı değerlere sahip olması beklenmektedir. Mesleki değer, çalışanların mesleğinde uygun olmayan ya da yasaklanan davranışlardan kaçınmasını, gereken ideal davranışları sergilenmesini sağlayan ölçütlerdir (Çelik ve Üstüner, 2017: 154). Mesleki etik, çalışanların mesleklerini icra ederken hem yasalara hem ahlaka uygun davranmalarını sağlayan kurallardır. Bu kurallar, haksızlıklara karşı gelmek, dürüst olmak, sözünde durmak, doğaya ve insana saygılı olmak gibi davranışları gerektirmektedir (Yoldaş, Işlak ve Şener, 2018: 24). Mesleki tutum ise çalışanların işi hakkındaki düşünceleri, hissettikleri ve buna bağlı olarak işinde gösterdiği performanstır. Dolayısıyla mesleğine karşı olumsuz bir tutum içinde olan, mesleğe ilgi duymayan ve sevmeyen çalışanların başarılı olmaları mümkün değildir (Altunkeser ve Ünal, 2015: 2).

Profesyonel bir meslek olarak turist rehberliğinde, mesleki başarının ve devamlılığının sağlanması meslek mensuplarının gerekli bilgi, beceri, tutum ve davranışlara sahip olmaları ve bu özelliklerini zamana uyum sağlayarak geliştirmelerine bağlıdır (İskender, 2011: 45). Turist rehberi, rehberlik ettiği bölgenin doğal, tarihi ve kültürel mirası hakkında geniş bilgi sahibi olmalı ve bilgisini turistlere iyi derecede hâkim olduğu en az bir yabancı dil ile aktarabilmelidir. Mesleki gelişimine katkı sağlayacak seminer, hizmet içi eğitim gibi faaliyetlere katılarak 
bilgisini geliştirmelidir. Turist rehberi öğrenme ve geliştirme, yönetim ve organizasyon iletişim, anlatım becerilerine sahip olmalıdır. Ayrıca rehberlerden görevini zamanında yerine getirme, disiplinli ve sorumluluk sahibi olma, kişisel bakımına dikkat etme, mesleki bilgisini geliştirme ve bunun için istekli olma gibi tutum ve etkili ve güzel konuşma, herhangi bir konuda ayrımcılık yapmama, gruba uygun davranışlar sergileme, oluşabilecek bir problem karşısında soğukkanlı davranabilme gibi davranışlar sergilemeleri beklenmektedir (Kozak ve Yetgin, 2013: 419).

Her meslekte o mesleğe kabul için gerekli şartlar bulunmaktadır. Turist rehberi olabilmek için de bireylerin birtakım şartları sağlamış olmaları gerekmektedir. 6326 sayılı Turist Rehberliği Kanunu ile düzenlenen bu şartlar; Türkiye Cumhuriyeti vatandaşı olmak, on sekiz yaşını doldurmuş olmak, üniversitelerin turizm rehberliği bölümlerinden ön lisans, lisans veya yüksek lisans mezunu olmak veya lisans düzeyinde herhangi bir bölümden mezun olup Bakanlık tarafindan düzenlenen sertifika programını tamamlamak, yabancı dil puanı en az 75 olmak, uygulama gezisini tamamlamak, mesleğe kabulü engelleyecek bir suçtan hüküm giymemiş olmak ve meslekten çıkarılmamış olmaktır. Bu şartları sağlayan bireyler Kültür ve Turizm Bakanlığı'na başvuru yapar ve kabul edilmesi halinde ruhsatname alırlar. Daha sonra bireyler kendilerine en yakın meslek odasına giderek üye olmak zorundadırlar. Böylece bir yıl geçerliliği olan çalışma kartına sahip olurlar. Dolayısıyla bu şartları sağlamayan bireyler turist rehberi olamaz ve bu mesleği yapamazlar.

Turist rehberliği mesleğini icra eden bireylerin başarılı bir meslek hayatı sürdürebilmeleri, kendilerini sürekli geliştiren ve işini büyük bir heyecan duyarak yapan çalışanlar olmalarıyla mümkündür. Ülkesini en iyi şekilde tanıtacak, ülke veya bölge hakkında olumlu imaj oluşturacak, turistlerin tekrar ziyaret etme isteği duymalarını sağlayacak, bilgi, beceri ve tutumlarıyla konuklarına iyi bir tatil deneyimi sunacak, turizm gelirlerinin artmasına ve rekabet avantajının sağlanmasına yardımcı olacak olan turist rehberleridir. Rehberlerin üstlendiği bu görev ve sorumlulukları yerine getirebilmesi mesleki açıdan donanımlı olmalarına bağlıdır (Albuz vd., 2018: 78). Bu bağlamda turist rehberleri turist grubunun tercih ettiği dilde anlatım yapmalı, ülkesinin veya grubunu gezdirdiği bölgenin tarihini, kültürünü, doğasını, sosyal değerlerini, çevresini iyi biliyor olmalı, kültür ve turizm politikalarını bilmeli ve bu esaslar dikkate alınarak düzenlenen tur programını uygulamalı, seyahat acentesinin düzenleyip satışa sunduğu tur programını içeriğinde yer alan bilgilendirme doğrultusunda gerçekleştirmelidir (Balta, 2017: 133).

\section{Yöntem}

\subsection{Araştırmanın Amacı ve Önemi}

$\mathrm{Bu}$ çalışmanın amac1, turist rehberlerinin kişisel ve mesleki yetkinliklerine ait görüşlerinin, kişisel gelişim çabalarının ve performans yeterliliklerine verdikleri önemin belirlenmesidir. Türkiye'de konuyla ilgili yapılan çalışmalar incelendiğinde, kişisel gelişime yönelik yapılan çalışmaların genellikle yönetici, bazı sektör çalışanları, öğretmenler ya da öğrenciler üzerine (Çoruk, 2007; Okyay, 2012; Balaban ve Çakmak, 2016) olduğu, turist rehberlerinin kişisel gelişimi üzerine kapsamlı bir çalışmanın bulunmadığı saptanmıştır. Fakat kişisel gelişimin alanına girebilecek motivasyon, liderlik, iletişim becerileri, kişilik özellikleri gibi konularda (Köroğlu, 2014; Bayram Erkol, 2017; Türkmen, 2017) turist rehberleri üzerine yapılmış çalışmalar bulunmaktadır. Mesleki donanım ise alanyazında mesleki yetkinlik konusu altında incelenmiştir. Turist rehberlerinin mesleki yetkinlikleri kapsamına girebilecek performans1, mesleki yeterliliği, meslek etiği algısı, yabancı dil yeterliliği gibi çalışmalara (Toksöz, 2015; Ünal, 2015; Cansu, 2018) son yıllarda artarak yer verilmeye başlanmıştır. Bu kapsamda çalışmanın ilgili alanyazına kaynak sağlayacağı düşünülmektedir. Çalışma ayrıca rehberlerin kişisel ve mesleki gelişim süreçlerinin ve bu sürece verdikleri önemin genel bir 


\section{IIIII)}

Turist Rehberliği Dergisi (TURED) \& Yıl. 2019, Cilt. 2, Sayı. 2

Journal of Tour Guiding (JOTOG) \& Year. 2019, Volume. 2, Issue. 2

profilini çizmektedir. Bunun yanı sıra lider pozisyonda çalışan farklı meslekten bireylere yönelik yapılabilecek araştırmalar için bir örnek teşkil edeceği düşünülmektedir.

Çalışmanın amacı kapsamında ilgili alanyazın incelenerek aşağıda belirtilen sorulara cevap aranmıştır. Sorular şu şekildedir: Turist rehberleri için kişisel ve mesleki gelişim önemli $\mathrm{mi}$ ? Turist rehberleri kişisel ve mesleki gelişimleri için çaba gösteriyorlar mı? Turist rehberleri sahip oldukları kişisel ve mesleki özelliklerini geliştirmek için ne yapmaktadırlar? Turist rehberlerinin kişisel ve mesleki yetkinlik düzeyleri nedir?

\subsection{Araştırmanın Tasarımı}

Çalışmanın amacı ve belirlenen araştırma soruları doğrultusunda, olay ya da olguları kendi ortamlarında incelemek, derinlemesine anlamlandırmak temel hedefiyle nitel araştırma yöntemi kullanılmıştır. Nitel araştırma, araştırılan olay ya da olguya ilgili bireylerin bakış açılarından bakabilmeyi ve bireylerin bakış açısını oluşturan süreçleri ve sosyal yapıyı ortaya koymayı sağlamaktadır (Coşkun vd., 2015: 303). Nitel verilerin elde edilmesinde ise fenomenoloji modelinden yararlanılmıştır. Bu model tanışı olduğumuz, günlük hayatta da karşımıza çıkan fakat hakkında ayrıntılı bilgi sahibi olmadığımız algı, yönelim, deneyim, kavram gibi olgulara odaklanmaktadır (Yıldırım ve Şimşek, 2016: 69).

\subsection{Evren ve Örneklem}

Çalışma amacına uygun olarak belirlenen İzmir Turist Rehberleri Odası'na bağlı olarak çalışan 776 eylemli turist rehberi (Turist Rehberleri Birliği, 2018) çalışmanın evrenini oluşturmaktadır. Fakat bu evrenin tamamına ulaşılması zaman ve maddi birtakım kayıplara neden olacağı için mümkün olmamaktadır. Bu nedenle evreni temsil edecek bir örneklem grubu oluşturulması gerekmektedir. Nitel araştırmalarda evreni temsil edecek örneklem büyüklüklerine çoğu zaman ulaşılamamaktadır. Bu noktada örneklem gruplarının evreni temsil gücü sınırlı kalmaktadır (Karataş, 2015).

Nitel araştırmalarda örneklemin seçilmesi temel olarak iki yönteme dayanmaktadır. Bunlar olasılıklı (amaçsız) ve olasılıklı olmayan (amaçl1) örnekleme yöntemleridir. $\mathrm{Bu}$ araştırmada olasılıklı örnekleme yöntemlerinden basit tesadüfi örnekleme yöntemi kullanılmıştır. Bu yöntemde, evrenden seçilen her elemanın eşit seçilme şansı vardır ve yapılan bir seçim diğer bir seçimi etkilememektedir. Seçimler sonucu oluşturulan örneklem gruplarının 5 ile 25 kişi arasında değişebileceği ilgili alanyazında belirtilmiştir (Yıldırım ve Şimşek, 2016: 118; Baltacı, 2018: 263). Bu doğrultuda çalışmanın örneklemini, İzmir Turist Rehberleri Odasına bağlı çalışan ve rastgele seçilen 15 eylemli turist rehberi oluşturmaktadır.

\subsection{Veri Toplama Aracı ve Verilerin Toplanması}

Çalışma kapsamında verilerin elde edilmesinde görüşme tekniği kullanılmıştır. Görüşme, araştırmacı tarafından katılımcıya birtakım sorular sorularak katılımcının konuyla ilgili düşünce ve gözlemleri hakkında bilgi edinilen süreçtir. Bu çalışmada yarı yapılandırılmış görüşme tekniğinden yararlanılmıştır. Bu teknikte, hazırlanmış olan sorular sırasıyla katılımcıya sorulur ve soruların katılımcı tarafından istenilen genişlikte yanıtlanmasına müsaade edilir (Yıkılmış ve Sazak Pınar, 2005: 11; Kozak, 2014).

Görüşme formunun hazırlanmasında Balıkesir Üniversitesi Turizm Fakültesi'nde turizm rehberliği bölümüne bağlı olarak görev yapan iki akademisyenden ve sektörde aktif olarak çalışan iki turist rehberinden görüş alınmıştır. 10 soru olarak hazırlanan görüşme formu, iki turist rehberiyle yapılan pilot bir uygulamanın ardından yeniden düzenlenerek 7 soru olarak görüşme formuna son şekli verilmiştir. Hazırlanan görüşme soruları şu şekildedir: 
1. Mesleğinizi seviyor musunuz? Neden?

2. Bir turist rehberini mesleğinde başarılı yapan kişisel ve mesleki özellikleri nelerdir? Bir turist rehberi olarak sizi mesleğinizde başarılı yapan kişisel ve mesleki özellikleriniz nelerdir?

3. Bir turist rehberinin grubuna karşı görünümü ve davranışları nasıl olmalıdır? Siz görünümünüze özen gösterir misiniz? Kişisel olarak zor zamanlar geçirdiğiniz bir dönemde grubuna karşı davranışlarınız nasıl olur? Grubunuzla veya grup üyeleri arasında yaşanan bir sorun halinde nasıl davranırsınız?

4. Bir konu veya durum hakkında meslektaşlarınızın bilgisine veya yardımına başvurur musunuz? Aranızda bir sorun yaşanması halinde mesleki ilişkilerinizi nasıl sürdürürsünüz?

5. Mesleki bilgi ve eğitiminizi yeterli görüyor musunuz? Günümüz değişen ve gelişen çağında bu değişime paralel bilgi ve eğitiminizi geliştiriyor musunuz? Geliştirmek için neler yapıyorsunuz?

6. Mesleki kongre, konferans, seminer veya toplantılara katılır mısınız? Bir turist rehberi için katılmasını gerekli görüyor musunuz? Neden?

7. Bir turist rehberi olarak meslekte yaşadığınız sorunlardan biraz bahseder misiniz? Meslekte yaşanan genel sorunlara (kaçak faaliyetler, düşük taban ücret vs.) çözüm getirebilmek için bireysel olarak neler yapıyorsunuz?

Turist rehberleriyle İzmir Turist Rehberleri Odası'na gidilip rehberlere ulaşma noktasında yardım talep edilerek ve İzmir bölgesindeki tarihi ve turistik mekânlara gidilerek iletişim kurulmuştur. Görüşmeler için randevular belirlenmiştir. Telefon aracıllğıyla ve yüz yüze yapılan görüşmeler katılımcı rehberlerin belirttiği zaman ve mekânda gerçekleştirilmiştir. Ortalama 20 dakika süren görüşmeler, katılımcı izni doğrultusunda kayıt altına alınmış ve gün sonu bilgisayara aktarılarak metin haline getirilmiştir. Veriler araştırmaya katılmayı gönüllü kabul eden 15 turist rehberinden Ocak-Mart 2019 tarihleri arasında toplanmıştır.

\subsection{Verilerin Analizi}

Görüşmeler sonucu elde edilen ve gün sonu bilgisayar ortamına aktarılarak metin haline getirilen veriler betimsel ve içerik analiziyle incelenmiştir. Metinler birkaç kez okunmuş ve bazı sözcük ve cümlelere isimler verilerek kodlamalar yapılmıştır. Oluşturulan kodlar sayısal olarak tekrar etme sıklıklarına göre gruplara ayrılmıs ve her bir grup ilgili bir temayla adlandırılmıştır. Analizler yapılırken herhangi bir bilgisayar programı kullanılmamıştır. İçerik analizinde tema oluşturma ve veriyi kavramsallaştırma çabası vardır. Betimsel anlatımla incelenen sonuçlarda ise sıkça doğrudan alıntılara yer verilir (Yıldırım ve Şimşek, 2016: 239). İçerik analiziyle oluşturulan kodlar ve kodlara atanan temalar, betimsel anlatımla yapılan yorumlamalar ve doğrudan alıntılar ayrıntılı olarak çalışmanın bulgular kısmında sunulmuştur. Doğrudan alıntılar tırnak işaretleriyle ayrılmış, katılımcılar R1, R2. şeklinde adlandırılmıştır.

\section{Bulgular}

Görüşmelere katılım gösteren turist rehberlerinin sosyo-demografik özellikleri incelendiğinde, cinsiyet değişkenine göre üç kadın ve 12 erkek turist rehberinden, yaş değişkenine göre 25-53 yaş aralığında farklı yaş gruplarından, öğrenim durumlarına göre ise bir doktora, bir yüksek lisans, dokuz lisans ve dört ön lisans mezunu rehberlerden oluştuğu belirlenmiştir. Katılımcı rehberlerin mesleki özellikleri incelendiğinde, mesleki rehberlik eğitimini 4 katılımcının bakanlık kursunda, 11 katılımcının üniversitede aldığ 1 , çalışma sürelerine bakıldığında 1-30 yıl arasında farklılık gösterdiği belirlenmiştir. Çalışma şekillerine

Gürsoy ve Karaman; Profesyonel Turist Rehberlerinin Kişisel Gelişimi ve Mesleki Donanımı Üzerine Bir

Araştırma / A Study on Personal Development and Professional Competence of the Professional Tourist Guides 


\section{IIIII)}

Turist Rehberliği Dergisi (TURED) \& Yıl. 2019, Cilt. 2, Sayı. 2

Journal of Tour Guiding (JOTOG) \& Year. 2019, Volume. 2, Issue. 2

göre 12 rehberin serbest, iki rehberin sözleşmeli ve bir rehberin kadrolu çalıştı̆̆ı, yabancı dillerine bakıldığında ise 10 rehberin İngilizce, iki rehberin Almanca, bir rehberin İngilizce, İspanyolca ve Portekizce, bir rehberin Fransızca ve bir rehberin Rusça dillerine sahip olduğu belirlenmiştir.

15 turist rehberiyle yapılan görüşmelerin analizlerinin yapılması sonucu oluşturulan kodlara ait temalar incelendiğinde bu temaların bir akademisyen görüşü de alınarak dört ana tema altında toplanmasının uygun olduğu belirlenmiştir. Bunlar sırasıyla; turist rehberliği mesleğine ilişkin görüşler, turist rehberlerinin kişisel ve mesleki özellikleri, turist rehberlerinin kişisel ve mesleki gelişim çabası ve turist rehberlerinin mesleki sorunlarla mücadelesidir. Oluşturulan dört ana tema ve bu temaları meydana getiren kodlar tablolar halinde sirasıyla ayrıntılı olarak incelenmiştir.

Tablo 1. Tema 1: Turist Rehberliği Mesleğine İlişkin Görüşler

\begin{tabular}{|c|}
\hline Temaya Ait Oluşturulan Kodlar \\
\hline $\begin{array}{l}\text { 1. Ülkesini, kültürünü, milli değerlerini, tarihini anlatmaya duyulan heyecan } \\
(R 4, R 5, R 6, R 10, R 11, R 14, R 15)\end{array}$ \\
\hline 2. Maddi ve sosyal imkânları $(R 3, R 7, R 12, R 13, R 15)$ \\
\hline 3. Yeni yerler keşfetmek $(R 1, R 5)$ \\
\hline 4. Yeni insanlar tanımak $(R 1, R 6)$ \\
\hline 5. Açık alanda çalışmak $(R 2, R 11)$ \\
\hline 6. Tarihe duyulan merak $(R 8, R 10)$ \\
\hline 7. Farkl1 deneyimler edinme $(R 9, R 12)$ \\
\hline 8. İsteğe bağlı çalışma $(R 6, R 13)$ \\
\hline
\end{tabular}

Birinci ana tema doğrultusunda katılımcıların görüşleri incelendiğinde sekiz kod ortaya çıkmıştır. Turist rehberlerinin mesleğe ilişkin görüşlerine bakıldığında ülkesini, kültürünü, milli değerlerini, tarihini anlatmaya duyulan heyecan, maddi ve sosyal imkânları en fazla vurgulanan noktalar olduğu görülmüştür. Örneğin katılımc1 R12: 'Tatmin edici gelir ve sosyal imkânlar sağllyor. Herhangi bir mesleğin sunamayacă̆l deneyimler edinme şansl veriyor.' , katılımc1 R4: 'Turiste ülkemizi, Türk kültürümüzü ne kadar iyi anlatırsam, karşımdakinin ön yargılarını ne kadar kırarsam o kadar başarılı sayıyorum kendimi. Bu yüzden bana bu mesleği sevdiren ülkem. ', katılımc1 R11: 'Baş̧ka meslek düşünemiyorum. Dört duvar arasında çalışamam. Bunun dışında yerli veya yabancı fark etmiyor karşında sonuçta bir insan var, karşındaki insana bilgini aktarabilmek, ben de aktarmayl seviyorum bu yüzden mesleğimi de seviyorum.', katılımc1 R6: 'Çalışmayacak olduğum durumlarda tur almama gibi bir esnekliğin olması. Her gün yeni insanlarla tanışlyor olmak çok keyifli. Ülkemi tanıtıyor olmak çok keyifli (R6)', katılımcı R8: 'Bana bu mesleği sevdiren tarih.', diyerek görüşlerini belirtmişlerdir.

Genel olarak görüşler değerlendirildiğinde, turist rehberlerinin mesleki bağlıllğını olumlu etkileyen, mesleklerini yerine getirirken kendilerine motivasyon kaynağı oluşturan nedenlerin ülkesini, tarihini, milli ve kültürel değerlerini aktarmaya duyulan sevgi ve mesleğin sağladığı maddi ve sosyal imkanlar olduğu görülmektedir. Bu noktada rehberlerin mesleklerine duygusal bir bağlılık duydukları ön plana çıkmaktadır. Turist rehberlerinin mesleklerine olumlu duygularla bağlanmaları, kendilerini mesleklerinde geliştirmeye daha istekli olmalarını sağlamaktadır. Özoğul ve Eğe (2018) turist rehberleri açısından mesleki bağl1lı̆̆ inceledikleri çalışmalarında, rehberleri mesleklerine bağlayan faktörler arasında duygusal bağlılığın ön plana çıktığını belirtmişlerdir. Mesleğe yönelik duygusal bağ ile rehberlerin, mesleklerine olumlu duygular besleyerek daha istekli bir şekilde mesleklerinde kendilerini geliştirebileceklerini belirtmişlerdir. Bu bağlamda meslekte gösterilecek gelişimin

Gürsoy ve Karaman; Profesyonel Turist Rehberlerinin Kişisel Gelişimi ve Mesleki Donanımı Üzerine Bir Araştırma / A Study on Personal Development and Professional Competence of the Professional Tourist Guides 
Turist Rehberliği Dergisi (TURED) \& Yıl. 2019, Cilt. 2, Sayı. 2

Journal of Tour Guiding (JOTOG) \& Year. 2019, Volume. 2, Issue. 2

destekleyici bir rolü olarak mesleğe duyulan duygusal bağın önemi ortaya çıkmaktadır. Çalışma kapsamında rehberlerden alınan görüşler duygusal bağlılığın ön plana çıktığını desteklemektedir.

Tablo 2. Tema 2: Turist Rehberinin Kişisel ve Mesleki Özellikleri

\begin{tabular}{ll|}
\hline \multicolumn{1}{|c|}{ Temaya Ait Oluşturulan Kodlar } \\
\hline 1. Temiz ve göze hoş gelen kıyafetler $(R 1, R 2, R 3, R 4, R 5, R 6, R 7, R 8, R 9, R 10, R 11, R 12, R 13, R 14, R 15)$ \\
2. Bireysel sıkıntıların yansıtılmaması için çaba gösterme $(R 1, R 2, R 3, R 4, R 5, R 6, R 7, R 8, R 9, R 10, R 12, R 13, R 14)$ \\
3. Sürekli okuma ve öğrenme çabası $(R 1, R 4, R 5, R 6, R 9, R 11, R 13, R 14, R 15)$ \\
4. Mesleğine sevgi ve ilgi duyma $(R 2, R 3, R 4, R 6, R 9, R 10, R 13, R 14)$ \\
5. Insanlarla iletişimi güçlü $(R 1, R 2, R 3, R 5, R 6, R 11, R 12)$ \\
6. Gündemi takip $(R 1, R 6, R 9, R 11, R 14, R 15)$ \\
7. Güler yüzlü, sıcakkanlı, samimi $(R 2, R 4, R 6, R 7, R 10)$ \\
8. Yabancı dil hâkimiyeti $(R 3, R 6, R 8, R 10, R 11)$ \\
9. Pazarlama becerisi $(R 7, R 11, R 12, R 15)$ \\
10. Beden dilini kullanabilme $(R 8, R 11, R 13, R 15)$ \\
11. Kendini ifade edebilme $(R 1, R 2, R 9)$ \\
12. Karş1sındakine güven verme $(R 4, R 6, R 7)$ \\
13. Kibar bir dil $(R 1, R 7)$ \\
14. Girişken $(R 1, R 6)$ \\
15. Lider $(R 1, R 3)$ \\
16. Kendine has duruş $(R 2, R 3)$ \\
17. Farklı anlatım tarzları $(R 2, R 5)$ \\
\hline
\end{tabular}

İkinci ana tema incelendiğinde katılımcıların görüşleri doğrultusunda 17 kod ortaya çıkmıştır. Turist rehberlerinin kişisel ve mesleki özelliklerine ilişkin görüşlerine bakıldığında temiz ve göze hoş gelen kıyafetler, bireysel sorunları yansıtmama çabası, sürekli okuma ve öğrenme, mesleğe duyulan sevgi ve ilgi en fazla vurgulanan noktalar olduğu görülmüştür. Örneğin katılımc1 R14: 'Merak, farklı kültürleri tanımaya meraklı kişiler, memleketini seven, öz eleștiri yapabilen. Çalışmak ve ögrenme isteği bașarıl yapar. Ben bu yașta hala okuyorum. Gündemi takip ediyorum. Mesleğinizi sevdiğiniz zaman başarll olursunuz zaten'. 'Ahlak kurallarını, konuşmayı, hitap etmeyi bilen. Rehber saygın insandır. Toplumdaki saygın insanlardır rehberler.' , katılımc1 R3: 'Dil kabiliyeti, ilgi duyması, rehberliğin gerektirdiği konularda arkeoloji olsun yerel kültür olsun sanat tarihi olsun öncelikle ona ilgi duymast gerekiyor. Bilgi ilgiyle edinilebilir. Ilgi ve merak, dile yatkınlı, birebir ilişkilerde kurabildiğim başarı beni başarılı yapan özellikler'. 'Duruş olarak kendinden emin bir duruşa sahip olmalı. Giyim kuşam olarak baktığımızda bu turun içeriğine göre değişir. Yani bir şehir turu yapıllyorsa örneğin biraz şık giyimli olması, diğer tur çeşitlerinde örneğin yürüyüş turları vs. daha rahat kiyafetler giyilebilir. Davranışı ise grubun lideri gibi davranması gerekiyor. Lider imajını yansıtmall. Tabi ki iletissim yeteneğinin oldukça yüksek olması gerekiyor. Tabi bu konuştuğu dilde öncelikle başarılı olmasını gerektiriyor.', katılımc1 R13: 'Birincisi dil, ikincisi bilgi, üçüncüsü tavır ve davranışlar. Saydlğım bu üç özellik beni başarılı yapan'. 'Klyafeti temiz olacak, kendisi de temiz olacak, beden dili önemli.' , diyerek görüşlerini belirtmişlerdir.

Genel olarak görüşler değerlendirildiğinde, mesleği gereği insanlarla birebir ilgilenen ve sürekli insan karşısına çıkan rehberlerin kişisel bakımlarına özen göstermesi gerektiği anlaşılmaktadır. Özellikle ilk izlenimde dış görünümün etkisi dikkate alındığında turist rehberlerinin temiz ve göze hoş gelen kıyafetler giymeye önem verdikleri anlaşılmaktadır. Daha önce de belirtildiği gibi işi gereği sürekli insanlarla vakit geçiren ve kendisi de bir insan olan turist rehberlerinin birtakım sorunlar yaşaması doğaldır. Bu noktada rehberlerin 


\section{IIIII)}

Turist Rehberliği Dergisi (TURED) \& Yıl. 2019, Cilt. 2, Sayı. 2

Journal of Tour Guiding (JOTOG) \& Year. 2019, Volume. 2, Issue. 2

yaşadıkları sorunları karşı tarafa yansıtmama konusunda çaba gösterdikleri görülmektedir. Ayrıca çok yönlü olmayı gerektiren bu meslekte rehberlerin sürekli okuma ve öğrenme çabası içerisinde oldukları ve mesleklerini severek ve ilgi duyarak icra ettikleri görülmektedir. Temizkan ve Arı (2019) turist rehberlerinin kişilik özelliklerini mesleğin gerekleri açısından değerlendirdikleri çalışmalarında, rehberlerin iletişimi kuvvetli, güler yüzlü, etkili konuşma becerisine sahip, araştırmacı, mesleki bilgiye sahip, lider gibi bazı özelliklere sahip olmaları gerektiğini belirtmişlerdir. Bu doğrultuda rehberlerin görüşleri değerlendirildiğinde mesleğin gerektirdiği birtakım kişisel ve mesleki özelliklere sahip oldukları ve bunların gelişimine önem verdikleri saptanmıştır.

Tablo 3. Tema 3: Turist Rehberinin Kişisel ve Mesleki Gelişim Çabası

\begin{tabular}{|ll|}
\hline \multicolumn{1}{|c|}{ Temaya Ait Oluşturulan Kodlar } \\
\hline 1. & Meslektaşlarının bilgi ve tecrübesine başvurma $(R 1, R 2, R 3, R 4, R 5, R 6, R 7, R 8, R 9, R 10, R 12, R 13, R 14$, \\
& $R 15)$ \\
2. Sürekli kendini yenileme $(R 1, R 2, R 4, R 5, R 6, R 7, R 8, R 9, R 10, R 11, R 12, R 14, R 15)$ \\
3. Mesleki toplantılara katılım çabası $(R 1, R 2, R 3, R 5, R 6, R 8, R 9, R 10, R 12, R 13, R 14, R 15)$ \\
4. Yoğun çalışma sebebiyle toplantılara katılamama $(R 4, R 7, R 11)$ \\
5. Bilgi ve yardım almaya gerek duymama ( $R 11)$ \\
\hline
\end{tabular}

Üçüncü ana tema incelendiğinde katılımcıların görüşleri doğrultusunda beş kod ortaya çıkmıştır. Turist rehberlerinin kişisel ve mesleki gelişim çabasına ilişkin görüşlerine bakıldığında meslektaşlarının bilgi ve tecrübesine başvurma, kendini sürekli yenileme, mesleki toplantılara katılma çabası en fazla vurgulanan noktalar olduğu görülmüsştür. Örneğin katılımc1 R5: Biz rehberler olarak tek bir alana bağlı çalışmıyoruz. Türkiye'nin herhangi bir yerinde ya da dünyanın herhangi bir yerinde çalışlyor olabiliriz. Bu durumlarda daha önce o bölgeye gitmiş rehberlerimizin bilgisine başvurabiliyoruz. Tabi bilgiyi olduğu gibi almıyoruz ama bir ön bilgi, bir destek olarak kullandiğımız doğrudur'. 'Üniversitede verilen eğitimi yeterli görmüyorum. Bir rehberin kendini geliştirmesinin en temel yolu okumaktan geçer diye düşünüyorum. Bunun yanı sıra kendimiz sivil olarak gitmemiz gereken bölgeleri gezip görmeye özen gösteriyoruz. Bunun yanı sıra meslek kuruluşlarının düzenlediği eğitim gezileri seminerler var. Bunlar da spesifik konular hakkında bilgi edinmemize yardımci oluyor'. 'Elimden geldiğince toplantılara katıllyorum.', katılımcı R2: 'Elbette. Gerçekten paylaşmayı seven, benden yaşça büyük görüp geçirmiş, paylaşmayı seven rehber abilerimden her zaman yardım isterim, fikir danışırım, onlarla sohbet etmeye çalışırım'. 'Üniversitede almış olduğumuz eğitim yeterli değil. Elbette okumak ve araştırmak gerek kitaplardan gerek farklı rehberlerin söylediklerini dinleyerek tabi bu bilgilerin de doğrudan değil araştırılarak alınması lazım. Ondan dolayı sürekli kendimi geliştirmeye çalışıyorum'. 'Elimden geldiğince katılmaya çalışırım. Bu işi güzel yapan rehber odaları var. Turum olmadiğı bir zamana denk getirdiğim ilk firsatta tekrar katılacağım. 'şeklinde görüşlerini belirtmiş̧lerdir.

Genel olarak görüşler değerlendirildiğinde, geniş bir bilgi ve beceriyi gerektiren, sürekli öğrenme ve tecrübe etmenin devam ettiği bu meslekte rehberlerin aynı anda her şeyden haberdar olmaları mümkün değildir. $\mathrm{Bu}$ bağlamda görüşlerden de anlaşılacağı üzere meslektaşlarının yardımlarına başvurmaları, onlarla iletişim halinde olmaları rehberlerin yararına olacaktır. Belirtildiği gibi öğrenmenin hayat boyu sürdüğü bu meslekte rehberler sürekli olarak kendilerini yenilemeli, güncel tutmalıdırlar. Bu noktada düzenlenen çeşitli seminer ya da toplantılar turist rehberleri için iyi bir firsat olarak görülmektedir. Lin, Lin ve Chen (2018) hazırlamış oldukları çalışmalarında mesleki bilgi, beceri ve profesyonel tutum boyutlarıyla ele aldıkları mesleki yeterliliği, turist rehberliği mesleği açısından temel nitelikler olarak ele almış ve rehberlerin bu boyutlara gereken düzeyde sahip olmaları, kendilerini eksik

Gürsoy ve Karaman; Profesyonel Turist Rehberlerinin Kișisel Gelișimi ve Mesleki Donanımı Üzerine Bir Araştırma / A Study on Personal Development and Professional Competence of the Professional Tourist Guides 


\section{IIIII)}

Turist Rehberliği Dergisi (TURED) \& Yı1. 2019, Cilt. 2, Sayı. 2

Journal of Tour Guiding (JOTOG) \& Year. 2019, Volume. 2, Issue. 2

gördükleri noktalarda kișisel ve mesleki gelișimlerini arttırıcı eğitim veya kurslar gibi birtakım faaliyetlerle kendilerini geliştirmeleri gerektiğini belirtmişlerdir. Bu doğrultuda katılımcı rehberlerin görüşleri de dikkate alındığında rehberlerin kişisel ve mesleki gelişimleri için çaba gösterdikleri anlaşılmaktadır.

Tablo 4. Tema 4: Turist Rehberinin Mesleki Sorunlarla Mücadelesi

\section{Temaya Ait Oluşturulan Kodlar}

1. Kaçak faaliyetlerin fotoğraflanıp ihbar edilmesi $(R 2, R 4, R 5, R 8, R 9, R 10, R 11, R 13, R 14, R 15)$

2. Acente kaynaklı oluşan sorunlar $(R 3, R 5, R 6, R 8, R 10, R 11, R 13, R 15)$

3. Taban ücret altı çalışmama $(R 1, R 5, R 6, R 7, R 12, R 14, R 15)$

4. Kaçak rehberlik, kaçak acentecilik $(R 2, R 3, R 8, R 12, R 13, R 15)$

5. Yoğun programlar ve sürekli yolda olma $(R 1, R 2, R 12, R 14)$

6. Rehberliğin meslek olarak görülmemesi veya değer verilmemesi $(R 6, R 8, R 12)$

7. Yapılan düzenlemelerin yetersiz kalması $(R 3, R 9, R 14)$

8. Yetersiz denetmen say1s1 $(R 1, R 3, R 10)$

9. Düzensiz hayat $(R 1, R 2)$

10. Gerekli durumlarda hukuksal yola bașvurma $(R 10, R 11)$

11. Krizi yönetebilme $(R 6, R 10)$

Dördüncü ana tema incelendiğinde katılımcıların görüşleri doğrultusunda 11 kod ortaya çıkmıştır. Turist rehberlerinin mesleki sorunlarla mücadelesine ilişkin görüşlere bakıldığında kaçak faaliyetlerin ihbar edilmesi, taban ücret altı çalışmama, acente kaynaklı sorunlar ve kaçak faaliyetler en fazla vurgulanan noktalar olduğu görülmüştür. Örneğin katılımc1 R10: 'Karşılaştığımız herhangi bir kaçak faaliyet durumunda fotoğraflarını çekip yetkili olan kişilere gönderiyorum. Tabi ki bunun şikâyetlerini yaplyorum. Ama maalesef bunun İzro'yla Tureb'le çok bir alakası olmamakla birlikte çok fazla sayıda denetimcimiz yok hem bütçeden hem de imkânlardan dolayı. Çünkü denetmenlerin yanında bakanlıktan da valilikten de insanları olmast gerekiyor. Aynı zamanda polis ve jandarmadan da insanların olması gerekiyor. Yani günümüzde çoğu yerde trafik polisi bile olmuyorken denetimler için polis atanması çok mümkün olmuyor. Belli zamanlarda belli bölgelerde daha çok o bölgeye tur yapılabileceğini tahmin ettiklerinde denetimler oluyor. Biz de bunlara elimizden geldiğince destek vermeye çallşlyoruz.', katılımc1 R9: 'Etik sorunları var mesleğin bir de yeterli olmayan kanunlar. Bazı arkadaşlara göre yeterli olsa bile kanunlar işlemiyor. Gördügümüz korsan ya da kaçak birim ya da şahısları ihbar ediyoruz. Fotoğraflarını çekip gönderiyoruz.' şeklinde görüşlerini belirtmişlerdir.

Genel olarak görüşler değerlendirildiğinde meslekte kanuna aykırı davranan kişi ya da acentelerden kaynaklanan veya kanundaki düzenlemelerin yetersizliğinden kaynaklanan birtakım sorunların yaşandığı görülmektedir. İlgili alanyazında rehberlerin yaşadıkları sorunlar ile ilgili çalışmalar incelendiğinde genel olarak benzer sorunların yaşandığı anlaşılmaktadır (Atay, 2008; Çetin ve Kızılırmak, 2012; Hacıoğlu vd., 2018). Bu noktada yetkili kişi, birim ya da bakanlığa görevler düştügü gibi rehberlerin de bireysel olarak üzerlerine düssen görevleri bulunmaktadır. Katılımcı rehberlerin bu konuda taban ücret alt1 çalışmayarak ve kaçak faaliyetleri ihbar ederek mücadele ettikleri anlaşılmaktadır.

Yapılan görüşmeler ile elde edilen verilerin analizi sonucunda katılımcı turist rehberlerinden iyi düzeyde olumlu yanıtlar alınmıştır. Mesleklerini seven, birtakım kişisel ve mesleki özelliklere sahip, kişisel ve mesleki gelişimleri için çaba gösteren ve meslekte yaşanan sorunlarla mücadele eden bireyler oldukları belirlenmiştir. 


\section{IIIII)}

Turist Rehberliği Dergisi (TURED) \& Yıl. 2019, Cilt. 2, Sayı. 2

Journal of Tour Guiding (JOTOG) \& Year. 2019, Volume. 2, Issue. 2

\section{Sonuç ve Öneriler}

Türkiye'nin $\mathrm{Bu}$ çalışma, turist rehberlerinin kişisel ve mesleki gelişimlerine verdikleri önemi, meslekleri ve sahip oldukları kişisel ve mesleki özellikleri hakkındaki görüşleri ve performanslarına verdikleri önemi ortaya koymaktadır. Çalışmada ilk olarak kişisel gelişim ve mesleki donanıma ilişkin alanyazın incelenmiştir. Daha sonra turist rehberleriyle görüşmeler yapılmış ve birtakım veriler elde edilmiştir. Elde edilen verilerin analiziyle bulgular ve sonuçlar ortaya koyularak çalışma sonlanmıştır. Verilerin toplanmasında yararlanılan görüşme formu ile katılımcıların demografik özellikleri, kişisel ve mesleki özellikleri, bilgi ve eğitimlerinin gelişimine verdikleri önem, bireysel ve mesleki sorunlarıyla mücadele konularında bilgiler elde edilmiştir. Katılımcıların demografik özellikleri incelendiğinde büyük çoğunluğun erkek ( $\mathrm{n}=12)$ ve lisans mezunu ( $\mathrm{n}=9)$ rehberlerden oluştuğu görülmektedir. Rehberlik mesleğinde sürekli yolda olma, uzun ve düzensiz çalışma saatleri gibi birtakım zorlukların olması ve aile hayatında kadının sorumluluğunun daha fazla olması nedenleriyle bu meslek kadın rehberler tarafindan daha az tercih edilmektedir. Ayrıca 2012'de çıkan 6326 sayılı Turist Rehberliği Meslek Kanunu ile mesleğe kabul şartlarında lisans ya da ön lisans mezunu olma şartı aranmaktadır. Mesleki özelliklerine göre ise çoğu rehberin mesleki eğitimini üniversitede $(\mathrm{n}=11)$ aldığı, yabancı dillerinin İngilizce $(n=10)$ olduğu ve serbest şekilde $(n=12)$ çalıştıkları belirlenmiştir.

Görüşme verilerinin analiz edilmesiyle verilerin dört ana tema altında toplanmasına karar verilmiştir. Birinci ana tema olan mesleğe ilişkin görüşler teması incelendiğinde, turist rehberlerinin mesleklerini severek icra ettikleri ve bu sevgiyi en fazla ülkesine, tarihine, kültürüne, milli değerlerine duyulan bağl1lı̆̆ın ve mesleğin sağladığı maddi ve sosyal imkânların tetiklediği belirlenmiştir. İkinci ana tema olan kişisel ve mesleki özelliklere ilişkin görüşler teması incelendiğinde, turist rehberlerinin sıcakkanlı, güler yüzlü, beden dilini kullanabilen, iletişimi güçlü, kendini ifade edebilen, lider, girişken, yabancı diline hâkim gibi birtakım özelliklere sahip oldukları; bireysel bakımına özen gösteren, gündemi takip, sürekli okuma ve öğrenme gayretiyle de gelişimlerine önem verdikleri anlaşılmaktadır.

Üçüncü ana tema olan kişisel ve mesleki gelişim çabasına ilişkin görüşler teması incelendiğinde, turist rehberlerinin bol kitap okuma, düzenlenen mesleki seminer ya da toplantılara vakit buldukça katılım göstermeye çalışma, meslektaşlarıyla bilgi alışverişinde bulunma gibi yöntemlerle gelişimleri için çaba gösterdikleri belirlenmiştir. Dördüncü ana tema olan mesleki sorunlarla mücadeleye ilişkin görüşler teması incelendiğinde, turist rehberleri mesleklerinde en fazla karşılaştıkları sorunların kaçak faaliyetler olduğunu belirtmişlerdir. $\mathrm{Bu}$ noktada rehberler yapılan düzenleme ve denetlemelerin yetersiz kaldığını ve gerekenin yetkililerce yapılması gerektiğini belirtmişlerdir. Bunun yanı sıra bireysel olarak rehberlerin taban ücret altı çalışmayarak, kaçak faaliyetleri ihbar ederek sorunlarla mücadele ettikleri belirlenmiştir.

Mesleğinde başarılı bir turist rehberi geniş bilgi birikimine sahip olan, bilgisini sürekli yenileyen ve mevcut bilgisine yeni bilgiler ekleyen başka bir deyişle kendini eğitmesini bilen rehberdir. Bu noktada kişisel ve mesleki gelişimin önemi ortaya çıkmaktadır. Sonuç olarak çalışmaya katılan turist rehberlerinin mesleğin gerektirdiği birtakım kişisel ve mesleki özelliklere sahip oldukları, kişisel ve mesleki gelişimlerine önem verdikleri ve bunun için çaba gösterdikleri saptanmıştır. Ayrıca son olarak aşağıda eğitim kurumlarına, turist rehberliği meslek kuruluşlarına, Turist Rehberleri Birliği' ne (TUREB), seyahat acentelerine ve diğer araştırmacılara öneriler sunulmuş̧ur.

Mesleki rehberlik eğitiminin verildiği üniversitelerde verilen bilgiler meslekte gerekli temel bilgiyi vermektedir. Ancak bu yeterli değildir. Eğitim kurumlarında verilen derslerin teorik olarak yeterli geldiği fakat mesleği rahat bir şekilde icra edebilmeyi sağlayacak pratik ve

Gürsoy ve Karaman; Profesyonel Turist Rehberlerinin Kişisel Gelişimi ve Mesleki Donanımı Üzerine Bir

Araştırma / A Study on Personal Development and Professional Competence of the Professional Tourist Guides 
uygulama noktasında yetersiz kaldığı Eker ve Zengin (2016) tarafından yapılan çalışmada da belirtilmektedir. Özellikle mesleki bilgini yanında kişisel ve mesleki gelişime katkı sağlayacak eğitimlerin de verilmesi gerekmektedir. Bu noktada üniversitelerde verilen dersler arasina kişisel ve mesleki gelişime katkı sağlayacak derslerin de eklenmesi önem arz etmektedir.

TUREB'e bağlı meslek kuruluşları uzmanlaşma eğitimi, eğitim gezisi gibi birtakım eğitim faaliyetleri yürütmektedir. Fakat düzenlenen bu eğitim faaliyetleri turist rehberlerinin mesleki gelişimlerine yönelik olmaktadır. Dolayısıyla rehberlerin kişisel gelişimini de destekleyecek faaliyetler düzenlenmelidir. Örneğin, farklı kültür, millet ya da inançtan oluşan bir grubu nasıl yönetmeleri, nasıl davranmaları konusunda destek verilebilir.

TUREB, kendisine bağlı meslek kuruluşlarının rehberlere yönelik seminerler düzenlemesi konusunda destek sağlamalıdır. Düzenlenecek olan bu seminerlerde özellikle kişisel gelişime katkı sağlanması noktasında bu konuda uzman bireylerle birlikte çalışılması gerekmektedir.

Turist rehberleri üstlendikleri görevler itibariyle ülkelerini temsil ettikleri gibi birlikte çalıştıkları seyahat acentalarını de temsil etmektedirler. Bu noktada farklı pazarlarla çalışan seyahat acentaları birlikte çalışııkları turist rehberlerinin ilgili pazara yönelik daha iyi bir hizmet sunabilmesi için rehberleri desteklemelidir. Örneğin acenta rehberlerinin faklı ülke veya bölgelere gitmelerine, oranın kültürüyle ve insanlarıyla etkileşim kurmalarına yardımcı olabilir. Aynı zamanda bu, kişisel gelişime de katkı sağlayacaktır.

Gelecekte yapılacak çalışmalarda, lider pozisyonda çalışan faklı mesleklerden bireyler üzerine benzer bir araştırma yapılabilir, farklı değişkenlerle bağdaştırılarak araştırma geliştirilebilir. Ayrıca turist rehberlerinin kişisel ve mesleki gelişimleri için yapılacak çalışmalarda rehberlerin ihtiyaçları göz önüne alınarak stratejiler belirlenebilir, çözüm önerileri sunulabilir.

\section{Kaynakça}

Akköz, H. (2015). Profesyonel Turist Rehberlerinin Sahip Olması Beklenen Nitelikleri İle Sergiledikleri Performansın Yerli Turistler Tarafından Değerlendirilmesi, (Yayınlanmamış Yüksek Lisans Tezi), Gaziantep Üniversitesi, Sosyal Bilimler Enstitüsü, Gaziantep.

Albuz, N., Köşker, H., Ercan, F. ve Özbek, Ö. (2018). "2017 Y11ı Turist Rehberliği Ön Lisans ve Lisans Eğitimine Yönelik Değerlendirmeler”, İçinde: N. Hacıŏlu, C. Avcıkurt, A. Kılıç ve H.U. Yıldırım (Ed.). Turist Rehberliği Üzerine Güncel Araştırmalar, 78-93, Ankara: Detay Yayıncilik.

Altunkeser, F. ve Ünal, E. (2015). Sınıf Öğretmeni Adaylarının Öğretmenlik Mesleğine İlişsin Tutumlarının Çeşitli Değişkenler Açısından Yordanması. Ahi Evran Üniversitesi Sosyal Bilimler Enstitüsü Dergisi, 2(1), 1-15.

Atay, L. (2008). Alan Kılavuzluğunun Çanakkale İlindeki Uygulaması ve İlgili Turizm Mevzuatı Açısından Değerlendirilmesi. Anatolia: Turizm Araştırmaları Dergisi, 19(2), 169 176.

Ayra, M. ve Kösterelioğlu, İ. (2015). Öğretmenlerin Yaşam Boyu Öğrenme Eğilimlerinin Mesleki Öz Yeterlilik Algıları ile İlişkisi. NWSA-Education Sciences, 10(1), 17-28.

Balaban, Ö. ve Çakmak, D. (2016). Üniversite Öğrencilerinin Kişisel Gelişim Eğitimlerine Yönelik Algılarının İncelenmesi. Sakarya İktisat Dergisi, 5(1), 1-17.

Balta. S. (2017). "Rehberlikte Kişisel Gelişim ve Paydaş İliş̧kileri”, İçinde: F.Ö. Güzel, V. Altıntaş ve İ. Şahin (Ed.). Turist Rehberliği Araştırmaları, Öngörüler ve Uygulamalar, 127139, Ankara: Detay Yayincilık. 
Baltacı, A. (2018). Nitel Araştırmalarda Örnekleme Yöntemleri ve Örnek Hacmi Sorunsalı Üzerine Kavramsal Bir İnceleme. Bitlis Eren Üniversitesi Sosyal Bilimler Enstitüsü Dergisi,7(1), 231-274.

Bayram Erkol, G. (2017). Motivasyonun Demografik Ve Mesleki Özelliklere Göre Farkl1laşması: Turist Rehberleri Üzerine Bir Araştırma. Journal of Yaşar University, 12(48), 257-271.

Biçer, G. ve Düztepe, Ş. (2003). Yetkinlikler ve Yetkinliklerin İşletmeler Açısından Önemi. Havacılık ve Uzay Teknolojileri Dergisi, 1(2), 13-20.

Cansu, E. (2018). Profesyonel Turist Rehberlerinin Eğitim Öğretim Dönemlerinde Aldıkları Yabancı Dil Eğitiminin Mesleki Açıdan Yeterliliği. (Yayınlanmamış Yüksek Lisans Tezi), Kastamonu Üniversitesi, Sosyal Bilimler Enstitüsü, Kastamonu.

Coşkun, R., Altunışık, R., Bayraktaroğlu, S. ve Yıldırım, E. (2015). Sosyal Bilimlerde Araştırma Yöntemleri Spss Uygulamal, 8. Bask1, Adapazarı: Sakarya Kitabevi.

Çelik, T. O. ve Üstüner, M. (2017). Ortaöğretim Öğretmenleri için Mesleki Değerler Ölçeği Geliştirme Çalışması. Uşak Üniversitesi Sosyal Bilimler Dergisi, 10(2), 151-169.

Çetin, G. ve Kız1lırmak, İ. (2012). Türk Turizminde Kokartl1 Turist Rehberlerin Mevcut Durumunun Analizi. Afyon Kocatepe Üniversitesi İktisadi ve İdari Bilimler Fakültesi Dergisi, 14(2), 307-318.

Çoruk, A. (2007). Okul Müdürlerinin Kişisel Gelişim Çabaları ve Birlikte Çalıştı̆̆ Öğretmenlerin Kişisel Gelişimlerine Katkıları. (Yayınlanmamış Yüksek Lisans Tezi), Çanakkale On sekiz Mart Üniversitesi, Sosyal Bilimler Enstitüsü, Çanakkale.

Doğan, Ö. (2018). Zaman Yönetimi ve Akademik Başarı İlişkisi: Artvin Çoruh Üniversitesi, Hopa İktisadi ve İdari Bilimler Fakültesinde Bir Uygulama. Artvin Çoruh Üniversitesi Uluslararası Sosyal Bilimler Dergisi, 4(1), 149-174.

Eker, N. ve Zengin, B. (2016). Turist Rehberliği Eğitiminin Değerlendirilmesi: Profesyonel Turist Rehberleri Üzerine Bir Uygulama. Eğitim ve Öğretim Araştırmaları Dergisi, 5(4), 65 74.

Ekşi, F. (2011). Kişisel Gelişim Literatürünün Eğitim ve Danışma İhtiyacı Açısından İncelenmesi: Kuramsal Analitik Bir Yaklaşım. (Yayınlanmamış Doktora Tezi), Marmara Üniversitesi, Eğitim Bilimleri Enstitüsü, İstanbul.

Genç, M. ve Fidan, Y. (2019). Öğrencilerin Kişisel Gelişim Yönelimlerinin Kariyer Uyum Yeteneklerine Etkisi: Üniversite Öğrencileri Örneği. İstanbul Ticaret Üniversitesi Sosyal Bilimler Dergisi, 18(35), 151-178.

Güneş, F. (2012). Blogna Süreci ile Yükseköğretimde Öngörülen Beceri ve Yetkinlikler. Yüksekögretim ve Bilim Dergisi, 2(1), 1-9.

Hacioğlu, N., Saylan, U. ve Sümbül, G. (2018). Türkiye'de Profesyonel Turist Rehberliğinin Sorunları ve Çözüm Önerilerine Yönelik Bir Araştırma, İçinde: N. Hacıŏlu, C. Avcıkurt, A. Kılıç, H.U. Yıldırım (Ed.). Turist Rehberliği Üzerine Güncel Araştırmalar, 446-467, Ankara: Detay Yayıncilık.

İskender, H. (2011). Türkiye'de Muhasebe Meslek Mensuplarının Mesleki Yetkinlik Sorunları ve $\mathrm{Bu}$ Sorunların Çözümünde Sürekli Eğitimin Rolü. (Yayınlanmamış Doktora Tezi), Sakarya: Sakarya Üniversitesi Sosyal Bilimler Enstitüsü.

Karahan, A. ve Kav S. (2018). Hemşirelikte Mesleki Yetkinlik. Hacettepe Üniversitesi Hemşirelik Fakültesi Dergisi, 5(2), 76-84.

Karataş, Z. (2015). Sosyal Bilimlerde Nitel Araştırma Yöntemleri. Manevi Temelli Sosyal Hizmet Araştırmaları Dergisi, 1(1), 62-80.

Karayağız, K. (2018). İlkokul Öğretmenlerinin Kurumsal Aidiyet Algısı ve Mesleki Yeterlilik Algısı Arasındaki İlişkinin İncelenmesi. (Yayınlanmamış Yüksek Lisans Tezi), İstanbul: Yeditepe Üniversitesi Eğitim Bilimleri Enstitüsü. 
Kassawnh, M. S., Makhadmeh, I. M., Shatnawi, H. S. and Najdawi, B. M. (2019). The Impact of Behaviors and Skills of Tour Guides in Guiding Tourist Groups. African Journal of Hospitality, Tourism and Leisure, 8(1), 1-13.

Kaya, U. ve Özhan, K.Ç. (2012). Duygusal Emek ve Tükenmişlik İlişkisi: Turist Rehberleri Üzerine Bir Araştırma. Çalışma İlişsileri Dergisi, 3(2), 109-130.

Kozak, A. M. ve Yetgin, D. (2013). Profesyonel Turist Rehberlerinin (PTR) Yetkinliklerinin Mesleki Yeterlilikler Çerçevesinde Değerlendirilmesi, İçinde: K. Karamustafa (Ed.). 14. Ulusal Turizm Kongresi Bildiriler Kitabl, 408-428, Erciyes Üniversitesi, Kayseri.

Kozak, M. (2014). Bilimsel Araştırma: Tasarım, Yazım ve Yayım Teknikleri. Ankara: Detay Yayınc1lik.

Köroğlu, Ö. (2014). Meslek Seçimi ile Kişilik Özellikleri Arasındaki İlişkinin Belirlenmesi: Turizm Rehberliği Öğrencileri Üzerine Bir Araştırma. Süleyman Demirel Üniversitesi İktisadi ve İdari Bilimler Fakültesi Dergisi, 19(2), 137-157.

Limoncu, A. (2015). Kişisel Gelişim Çabası ve İş Tatmini Arasındaki İlişsinin İncelenmesi: Hekim ve Hemşireler Üzerine Bir Araştırma. (Yayınlanmamış Yüksek Lisans Tezi), Süleyman Demirel Üniversitesi, Sosyal Bilimler Enstitüsü, Isparta.

Lin, Y.-C., Lin, M-L. and Chen, C-Y. (2018). Examining the Impact of Tour Guides' Professional Competences on Service Quality, Tourist Satisfaction and Repurchase Intentions towards Package Tour Products. Journal of Tourism and Hospitality Management, $6(2), 26-38$.

Lovrentjev, S. (2015). Education of Toursit Guides: Case of Croatia. Procedia Economics and Finance, 23, 555-562.

Okyay, B. (2012). Yönetici ve Çalışanların Özgüven Düzeyleri ile Kişisel Gelişim İnisiyatifi Alma Becerilerinin Karşılaştırılması. (Yayınlanmamış Yüksek Lisans Tezi), Maltepe Üniversitesi, Sosyal Bilimler Enstitüsü, İstanbul.

Özoğul,G. ve Eğe, Z. (2018). Mesleki Bağlılık: Tanımı, Boyutları ve Turist Rehberliği Açısından Önemi. Akademik Sosyal Araştırmalar Dergisi, 6(66), 366-384.

Pekkan, N.Ü., Gökçen K.A., Develi, A. ve Çavuş, M.F. (2018). Kariyer Tatmini Kişisel Gelişim Yönelimi Görev Performansı ve Bağlamsal Performans İlişkisini Belirlemeye Yönelik Bir Araştırma", İçinde: N. Kalkan, T. Kaplan ve T. Nas (Ed.). 26. Ulusal Yönetim ve Organizasyon Kongresi Bildiriler Kitabı, 771-777, Karadeniz Teknik Üniversitesi Trabzon.

Saltık Arıkan, I. ve Dönmez Gümüş, F. (2018). Turist Rehberleri ve Kişilik, İçinde: S. Eser, S. Şahin ve C. Çakıcı (Ed.). Turist Rehberliği, 75-100, Ankara: Detay Yayıncılık.

Şahin, S. ve Kızılırmak, İ. (2018). Turist Rehberliği Mesleki Etik İlkeleri, İçinde: S. Eser, S. Şahin ve C. Çakıcı (Ed.). Turist Rehberliği, 221-238, Ankara: Detay Yayıncılık.

Tat, M. (2007). Zihin Dili Programlaması(NLP)nın Kişisel Gelişim ve Kişilerarası İletişim Üzerindeki Etkisi: NLP Eğitimlerinin, Kişisel Gelişim, Örgütlerde Kişilerarası İletişim ve Performans Geliştirme Üzerindeki Etkilerine İlişkin Bir Araştırma. (Yayınlanmamış Doktora Tezi), Ege Üniversitesi, Sosyal Bilimler Enstitüsü, İzmir.

Temizkan, P. ve Arı, Ö. (2019). Turist Rehberi Adaylarının Kişilik Özelliklerinin Mesleğin Gerekleri Açısından Değerlendirilmesi, Journal of Gastronomy Hospitality and Travel, 2(1), 65-79.

Toksöz, D. (2015). Turist Rehberlerinin Meslek Etiği Algısının Ölçülmesi. (Yayınlanmamış Yüksek Lisans Tezi), Mersin: Mersin Üniversitesi Sosyal Bilimler Enstitüsü.

Turist Rehberleri Birliği (TUREB). Rehber İstatistikleri. http://tureb.org.tr/tr/RehberIstatistik/ (Erişim Tarihi: 20.07.2019)

Turist Rehberliği Meslek Kanunu, (2012), T.C. Resmi Gazete, 28331, 22 Haziran 2012.

Türkmen, T. M. (2017). A Research on Determination of Leadership Orientations of Tourist Guides. Gaziantep University Journal of Social Sciences, 16(3), 913-927. 
Ünal, C. (2015). Profesyonel Turist Rehberlerinin Mesleki Yeterliliklerinin Turistlerin Destinasyon İmaj Algıs1 ve Genel Memnuniyeti Üzerine Etkisi (Alman Turistlere Yönelik Antalya Şehir Turunda bir Uygulama). (Yayınlanmamış Yüksek Lisans Tezi), Antalya: Akdeniz Üniversitesi Sosyal Bilimler Enstitüsü.

Yıkılmış, A. ve Sazak Pınar, E. (2016). İlköğretim Okulu Müdürlerinin Kaynaştırmaya Yönelik Görüşlerinin Belirlenmesi. Abant İzzet Baysal Üniversitesi Eğitim Fakültesi Dergisi, 5(1), 722.

Yıldırım, A. ve Şimşek, H. (2016). Sosyal Bilimlerde Nitel Araştırma Yöntemleri. Ankara: Seçkin.

Yoldaş, C., Ișlak, O. ve Şener, A.N. (2018). Akademisyenlerin Mesleki Etik Davranışlarına İlişkin Sınıf Öğretmeni Adaylarının Görüşleri. International Journal of Active Learning, $3(2), 23-33$. 